\title{
Articles
}

\section{Learner Characteristics of Early Starters and Late Starters of English Language Learning: Anxiety, Motivation, and Aptitude}

\author{
Tomoko Takada \\ Gakushuin Girls'Junior E Senior High School
}

Two groups of first-year Japanese students at a private junior high school (JHS) were compared in their foreign language (FL) anxiety, three constructs of motivation (interest in FL, instrumental motivation, need for achievement), and language learning aptitude. The first group experienced FLES (Foreign Language in Elementary School) and the second group had no FLES experience. The results revealed that the learners with no FLES experience felt a significantly stronger "need for achievement," whereas the two groups did not differ in the other constructs of motivation and anxiety. These findings suggest that anxiety and motivation may be more strongly affected by factors other than the starting age of FL learning. Thus caution is called for, so as to not overestimate FLES as a motivation booster. Although no statistical difference was seen in aptitude, the learners without previous FLES experience showed somewhat higher inductive learning abilities than their FLES-experienced counterparts. This finding warns against including selection bias in comparative studies of FLES and non-FLES students at private JHSs in Japan.

私立中学 1 年の生徒を、小学校で英語を学んだグループ、学ばなかったグループに分け、 両者の (a) 外国語学習への不安、(b) 動機（外国語への関心、道具的動機、達成の必要性）(c) 言語学習の適性、を比較した。その結果、未経験者が経験者よりも、達成の必要性を強く感 じていることが明らかになった。動機のその他の下位区分および不安においては、優位差を 認めなかった。この結果は、外国語学習への不安や動機が複雑な概念であり、学習開始年齢 以外の要因をより強く受ける可能性を示唆する。小学校での英語教育が英語への興味や関心 を育てるとして注目されているが、その効果を過度に期待することへの警告と解釈できる。 言語学習の適性においても優位差は認めなかったが、記述的統計では未経験者が経験者より もかなり高い帰納的学習能力を示した。これは、小学校での英語教育の効果を私立中学で調 査する場合、選択の偏りに注意すべきことを示唆する。

JALT Journal, Vol. 25, No. 1, May, 2003 
$\mathrm{T}$ he effect of foreign language learning in elementary school has been a controversial issue for decades in Japan as well as in other countries where English is not the first language. Indeed, it has attracted wider, more serious attention since the Ministry of Education, Culture, Sports, Science, and Technology decided to include Foreign Language in Elementary School (FLES) as an optional activity in a new general studies course that was implemented in 2002. Some researchers and educators suspect that FLES will make little difference (Kobayashi, 1996; Shirahata, 1998, 1999, 2002) whereas others emphasize its virtues (Higuchi, 1987, 1990, 1999; Ito, 1987, 1990, 1997; Kuniyoshi, 1996; Kuno, 1987, 1990; Nakayama, 1990). There is yet a middle position. Asaba, Ishida, and Kobayashi (1998) conducted a nationwide survey to investigate university-level English teachers' views on the introduction of FLES. They found that $62 \%$ of English instructors at four-year universities showed no response when asked if they agreed or disagreed with the introduction of FLES. Asaba et al. explain that this finding suggests that the respondents were not yet ready to propose an answer to this question.

The disagreement among educators and researchers implies the complex nature of this issue. There is little agreement about the degree of importance the critical period hypothesis $(\mathrm{CPH})$ plays in second and/or foreign language learning. Some researchers support the $\mathrm{CPH}$ on the condition that learners are exposed to the target language in a natural setting for an extended period (Krashen, Long, \& Scarcella, 1979; Patkowski, 1980; Shirahata, 1994). Ito (1987, 1997) supports the CPH when there is formal instruction as well as informal learning, arguing that a foreign language (FL) that is acquired in childhood stays in the brain and can be activated when learners grow older. Other researchers present survey results or experimental studies that challenge the $\mathrm{CPH}$ (Burstall, 1975; Ekstrand, 1982; Nikolov, 2000; Snow \& Hoefnagel-Höhle, 1977). In their extensive literature review on age and second language acquisition, Marinova-Todd, Marshall, and Snow (2000) criticize misconceptions regarding the effects of age difference on speed and ultimate levels of acquisition, and caution that administrators and parents should not proceed on the assumption that only early FL teaching will be effective. McLaughlin (1992) also contends that with regard to school settings the younger-is-better hypothesis does not have strong empirical support. Fledge (1987) argues against accepting the CPH on the grounds that the adult-child difference is likely to arise from a variety of factors other than a critical period because the age of learners is inevitably confounded with other conditions that co-vary with chronological age. 
Another reason for the disagreement on the age issue, particularly among Japanese EFL teachers and researchers, may be the scarcity of empirical studies conducted in the Japanese EFL setting. Several studies have investigated the effects of FLES on learners' achievement, but these efforts have met with conflicting results. There is a position that claims that FLES produces a long-term beneficial effect, whereas another position claims that the effect of FLES is dubious.

Higuchi and his associates maintain the first position. One of their series of empirical studies, Higuchi, Kitamura, Moriya, Miura, \& Nakayama (1986), made cross-sectional comparisons in speaking skills between FLES and non-FLES groups at three grade levels: the $7^{\text {th }}, 9^{\text {th }}$, and $11^{\text {th }}$ grades. The FLES group outperformed their non-FLES counterpart in the $7^{\text {th }}$ grade but no statistical differences were found in the $9^{\text {th }}$ and $11^{\text {th }}$ grade levels. However, they predict that FLES is effective for two reasons: first, the $11^{\text {th }}$ grade FLES students earned higher scores descriptively, and second, another study they presented in 1985 showed that FLES students had more favorable attitudes toward English speaking communities than non-FLES students. In another study that compared the story-telling ability of FLES and non-FLES students at the $7^{\text {th }}, 9^{\text {th }}$, and $11^{\text {th }}$ grade levels, Higuchi, Kitamura, Moriya, Miura, Nakayama, and Kunikata (1987) found that the $11^{\text {th }}$ grade FLES students uttered a significantly larger number of sentences than the non-FLES students but no significant differences between the two groups were found at the $7^{\text {th }}$ and $9^{\text {th }}$ grade levels. Although the sample sizes in these two studies are relatively small, with each cell size being 11 or 12, Higuchi (1987) argues that FLES is effective in the long run. In addition, he predicts that the difference in speaking skills between FLES and non-FLES groups will be larger when they become college students on the grounds that more FL utterances produced by FLES students can lead to more opportunities for hypothesis testing, which is crucial for interlanguage development.

Megumi, Yokoyama, \& Miura (1996) conducted a study to test Shichida's (as cited in Megumi et al., 1996) and Ito's (as cited in Megumi et al., 1996) claims that FLES generates beneficial effects. They administered listening and reading tests to FLES and non-FLES students at the $8^{\text {th }}, 9^{\text {th }}$, and $10^{\text {th }}$ grade levels, finding statistically significant differences at every grade level on the listening test. However, none of the three grade levels showed statistical differences on the reading test.

Three studies support the second position that the effect of FLES is dubious. Tokyo Kyoiku Daigaku Fuzoku Chugakko Eigo Ka (1970), the English department of the junior high school attached to Tokyo College 
of Education, administered a pretest and a posttest of aural perception and aural comprehension in April and June of 1970 to its first year students. Their results showed that the non-FLES group caught up with their FLES counterpart in two months. Oller and Nagato (1974) used a cloze test as an instrument, finding that there was a significant difference between FLES and non-FLES students at the $7^{\text {th }}$ grade level, the first year of English language learning at junior high school (JHS). This difference had declined by the $9^{\text {th }}$ grade though it was still significant. By the $11^{\text {th }}$ grade, however, the differences were no longer statistically significant.

Special attention should be paid to Shirahata (2002) in that his FLES participants, unlike those in other studies, learned English in public ESs designated by the Ministry of Education as pilot study schools where FLES was introduced before its official introduction in the 2002 academic year. He compared FLES and non-FLES groups in listening and speaking skills eight months after they started to learn English in JHS. The results showed no statistical differences between the two groups in any of his three test instruments, which led him to conclude that the pedagogical suggestions presented in the handbook for Elementary School (ES) English activities published by the Ministry of Education Culture, Sports, Science and Technology (2001) may not greatly contribute to language acquisition.

Studies looking at the effect of FLES on learner characteristics are more limited despite the traditional notion that FLES has a positive effect on learner characteristics, such as motivation. One of the few studies, for example, is Higuchi, Kunikata, Miura, Kitamura, Nakamoto, and Moriya (1994), who investigated a total of 1114 students enrolled in the $7^{\text {th }}, 9^{\text {th }}$, and $11^{\text {th }}$ grades and 303 college freshmen. Their survey results showed no significant differences between early starters and late starters of English learning in the total scores obtained for both integrative and instrumental motivation. At the same time, however, they report that FLES students scored higher in two out of four question items. They were (1) I am interested in talking and making friends with Englishspeaking people, and (2) I am interested in talking and making friends with people from other countries. Based on these findings, Higuchi et al. (1994) conclude that FLES-experienced learners have higher integrative motivation than FLES-inexperienced learners. Despite abundant anecdotal reports that FLES enhances learners' interest in the culture of a target language as well as the language itself, empirical evidence is scarce. Further studies on this issue are needed because motivation, which is viewed as a key factor in language learning (Ellis, 1994), is a 
crucial concept in the Japanese educational setting. According to the Ministry of Education (2001, p. 2) FLES in Japan does not aim so much at language acquisition as at the enhancement of motivation.

Anxiety, another important factor in FL acquisition (Dulay, Burt, \& Krashen, 1982; Horwitz, Horwitz, \& Cope, 1986; MacIntyre \& Gardner, 1991; 1994), has been neglected in FLES/non-FLES comparative studies. This affective factor needs careful investigation because FLES is included as an optional activity, in the new general studies course, a JHS English class can consist of students from an ES that has implemented FLES and students from another ES that has not. This has already been the case at some private JHSs that accept non-FLES students from public ESs as well as FLES students from their affiliated ESs. Under such circumstances inexperienced learners may feel they are behind and therefore may exhibit a higher anxiety level in the language classroom. However, researchers and educators, who have been preoccupied with the introduction of FLES, seem to show little concern for these learners.

The present study attempts to fill this gap by comparing experienced and inexperienced learners of English with regard to FL anxiety and motivation. Are non-FLES students more nervous and anxious about learning English because of their lack of language learning experiences? Are FLES students more motivated toward language learning? These questions need to be answered not only to assess the effect of FLES but also to identify the different educational needs of experienced and inexperienced learners, if any, so that JHS teachers can meet their needs and expectations.

Foreign language anxiety has been extensively studied in social psychology, educational psychology, and speech communication. Second/foreign language (SL/FL) researchers have for some time been aware that anxiety prevents SL/FL learners from performing successfully, but the first to isolate FL anxiety from other forms of anxiety were Horwitz, Horwitz, and Cope (1986). They conceptualize language anxiety as "a distinct complex of self-perceptions, beliefs, feelings, and behaviors related to classroom language learning arising from the uniqueness of the language learning process" (1986, p.128). They maintain that FL anxiety is distinct from other academic anxieties because the immature command of the FL threatens learners' selfperceptions and self-esteem. MacIntyre and Gardner (1991) echo the Horwitz et al. (1986) argument, suggesting that language learning classes can be more anxiety-provoking than other courses. This assumption is also supported by a qualitative study conducted by Price (1991), who 
interviewed ten FL learners to obtain learner perspectives on anxiety. She speculates that FL courses may be more demanding, and therefore may elicit higher anxiety than other courses.

The complex nature of the relationship between anxiety and classroom performance has been well documented. In his extensive review of anxiety research, Scovel (1991) identifies a number of intervening variables: intelligence, stage of learning, difficulty of task, and familiarity of task. Citing Beeman, Martin, and Meyers, Scovel suggests that increased anxiety is more likely to negatively affect academic performance of learners at earlier stages than at later stages. Task requirements can be another variable. Horwitz et al. (1986) argue that listening and speaking are more anxiety inducing. Considering that EFL beginning-level classes often place emphasis on listening and pronunciation, we have good reason to think that beginners may be more apprehensive.

Motivation, another variable to be examined in the present study, is defined as "the combination of effort, desire to achieve the goal of learning the language, and favorable attitudes toward learning the language" (Gardner, 1985, p. 10). The distinction made in Gardner's social-psychological model between integrative motivation and instrumental motivation (Gardner \& Lambert, 1972), has long been predominant in the field of second language acquisition. However, Gardner's approach has been challenged in the past two decades. Based on an extensive literature review, Au (1988) contends that Gardner's theory is not supported by empirical evidence. Au examined fourteen studies conducted by Gardner and his associates, reporting that seven found no relationship between integrative motivation and second language achievement and that four found a negative relationship. Crookes and Schmidt (1991) claim that Gardner's approach "has been so dominant that alternative concepts have not been seriously considered" (p. 501). Recently, however, an alternative has been presented by Noels (2001). Her comprehensive theoretical framework combines integrative orientation with intrinsic and extrinsic orientations. Whereas Gardner's model was developed based mainly on studies conducted in bilingual situations, and therefore, may not be applicable to FL situations where the target language is not in everyday use, Noels's model emphasizes "the important role that social milieu has for learners' motivation" (p. 61). It reflects the claim that integrative and instrumental orientations should be conducted "within an experimental context which permits the emergence of other orientations characterizing a given population" (Clément \& Kruidentier, 1983, p. 276). 
One of the contextual factors that can influence motivation is the ESL/ EFL distinction. Based on the assumption that the results obtained from the studies on motivation in ESL contexts are not directly applicable to EFL situations, Dörnyei (1990) administered a motivational questionnaire to EFL learners in Hungary and identified seven motivational components. Of these, he found that two components, instrumental motivation and "need for achievement", contribute considerably to the attainment of an intermediate level of proficiency whereas the desire to go beyond this level is associated with integrative motivation. Another study that investigated a motivational construct in an EFL setting is Konishi (1990, cited in Konishi 1994). Factor analysis results obtained from Japanese JHS students identified "interest in English" along with integrative and instrumental motivation. She argues that "interest in English" is a component typical of the Japanese social and educational context, where English is not a medium of communication.

Based on these EFL factor analysis studies, the present study investigates three components of motivation: (a) interest in FLs and FL-speaking people, (b) instrumental motivation, and (c) need for achievement. Interest in FL and FL-speaking people is particularly relevant to educational policy in Japan since FLES has been introduced to promote international/intercultural understanding in children (Ministry of Education, 2001, p. 2).

In addition to anxiety and motivation, the present study also investigates the language learning aptitude of FLES and non-FLES students. Unlike anxiety or motivation, aptitude is seen as a relatively stable factor, not likely to be improved through training (Carroll, 1981). Aptitude is nonetheless of interest for comparative studies of FLES and non-FLES groups, particularly from a methodological perspective. The FLES/nonFLES distinction in the Japanese school system includes confounding variables, one of which is aptitude. In most of the studies comparing FLES and non-FLES students in Japan, the FLES participants were students from private JHSs who learned English in the affiliated private ESs because English language teaching was not part of the curriculum in public schools before 2001. These students are admitted to private ESs through a screening process at age six and are promoted to the affiliated JHSs automatically whereas their non-FLES counterparts are accepted to private JHSs through a different screening process, commonly by taking entrance examinations in academic subjects. Selecting students at different developmental stages through different processes might result in selecting students who are different in cognitive abilities and family 
backgrounds. If FLES and non-FLES students enrolled in a private JHS differ with regard to factors that are not directly related to the starting age of learning English, we should exercise caution in interpreting previous studies as well as in designing future studies. Study results would be expected to exert pedagogical influence as well because if a study infers the superiority of one group over another, it should be reflected in syllabuses and methodologies in JHSs.

Aptitude is distinct from intelligence and refers to the special ability involved in language learning (Ellis, 1985). Carroll (1981) claims that separate dimensions of FL aptitude exist and make independent contributions to the prediction of FL learning success. He identified four factors in aptitude: phonemic coding ability, grammatical sensitivity, inductive language learning ability, and rote learning ability. This theoretical framework led to the development of Carroll and Sapon's Modern Language Aptitude Test (MLAT), an instrument widely used to measure aptitude for screening and selection purposes (Carroll, 1981) as well as for research. Carroll cites a number of studies that used the MLAT as a control variable to screen or match experimental groups. Skehan (1989) emphasizes the multidimensionality of aptitude in educational terms. He argues that a more differentiated view of aptitude could be the basis for more effective teaching. The present research intends to measure FLES and non-FLES students' aptitude for both methodological and pedagogical purposes.

The following question is addressed in this study: How do JHS students who did not learn English in ES (non-FLES students) differ from JHS students who did (FLES students) in: foreign language anxiety, three constructs of motivation (interest in FL and FL-speaking people, instrumental motivation, need for achievement) and language learning aptitude?

\section{Methods \\ Participants}

One hundred forty-eight female students enrolled in the first year of a private all-girls' JHS in the Tokyo metropolitan area participated in the study. Out of an intact student body of 204, 56 students were eliminated from the study. They were students who had (a) lived in Englishspeaking countries for more than one year, (b), attended ESs that did not offer a FLES program but studied English in after-school programs with tutors or at language schools, or (c) missed taking the aptitude test. 
The students who belonged to the first two categories were identified by response to a preliminary background questionnaire.

Of the remaining 148 students, 61 were in the FLES group and 87 belonged to the non-FLES group. The FLES students had studied English for three years from the fourth to the sixth grade as an academic subject at a private ES affiliated with the JHS in which they were currently enrolled. The time allotted for English learning was one hour per week in the $4^{\text {th }}$ and $5^{\text {th }}$ grades and two hours per week in the $6^{\text {th }}$ grade. According to personal communication between their ES English teacher and this researcher, the objectives of instruction were to develop the children's interest in English and to cultivate positive attitudes toward language learning, just as is stipulated in the guidelines from the Education Ministry (2001). The instruction focused on listening and speaking, but it included some activities that involved writing.

In JHSs, the FLES and non-FLES students receive English instruction in separate classes in their first year. The teaching materials are the same, but the FLES classes cover the materials for a shorter period of time during the first term by skipping the introduction of words and phrases already familiar to the students. Extra time is spent on additional communicative activities FLES classroom. In the second and third terms, the content and the speed are the same for both FLES and non-FLES classes

\section{Instruments}

Three instruments were prepared to measure individual differences in FL anxiety, motivation, and language learning aptitude.

\section{Foreign Language Anxiety}

FL anxiety was measured by administering a modified version of the Foreign Language Classroom Anxiety Scale (FLCAS), which was developed by Horwitz, Horwitz, and Cope (1986). The original version of the FLCAS consists of 33 items that reflect communication apprehension, test-anxiety, and fear of negative evaluation in the FL classroom. The number of items in the original version was reduced to 20 by eliminating the statements that did not apply to beginners or to the participants' current learning context. For example, "Even if I am well prepared for language class, I feel anxious about it" and "I don't feel pressure to prepare very well for language class" were eliminated because preparation was not expected in the beginners' class. The entire questionnaire was 
translated into Japanese.

Thirteen items, which were positively keyed, were followed by a five-point scale with 1 being "strongly disagree" and 5 being "strongly agree." The other seven items, which were negatively keyed, were followed by a five-point scale with 1 being "strongly agree" and 5 being "strongly disagree." Thus, the smaller numbers on the scale represented less anxiety in all 20 statements. Possible scores ranged from 20 through 100: the larger the number, the higher the anxiety level.

At the end of the survey, an open-ended question was added, in which the participants were asked to write any concerns they had about learning English. The researcher hoped that qualitative data would provide some useful information in interpreting the results obtained from the quantitative test instruments, as suggested by Brown (2001).

\section{Motivation}

For each of the three motivational components examined, four statements were prepared. They were based on Dörnyei's (1990) questionnaire items comprising 18 motivation/attitude variables. This motivational questionnaire, developed for adult learners in Hungary, was modified to suit the particular context of this preliminary study. Each item was followed by a five-point scale with 1 being "strongly disagree" and 5 being "strongly agree". Possible scores in each section ranged from 4 to 20: the larger the number, the stronger the motivation. Administrative concern over limited available time and these young students having to complete a lengthy questionnaire called for a smaller number of items to measure each motivational construct.

The 12 motivation items were combined with the 20 anxiety items into one questionnaire sheet, all written in Japanese (see appendix for Japanese and English versions). Approximately 20 minutes was allowed to complete the questionnaire.

\section{Language learning aptitude}

Language learning aptitude was measured by administering a test called the Lunic Language Marathon (LLM), which was developed specifically for Japanese EFL learners (Sick \& Irie, 2000). This test asks test takers to learn an artificial language called Lunic. Borrowing its format from the Modern Language Aptitude Test (MLAT) and the Pimsleur Language Aptitude Battery (PLAB), it consists of four parts, which measure the following constructs: (a) auditory memory and learning ability, (b) phonemic coding ability, (c) rote learning ability and a preference for 
visual learning, and (d) inductive language learning ability and a preference for analytical learning tasks. Possible scores in each part ranged from 0 through 100. The time allotted to complete this was 50 minutes.

\section{Procedures}

The LLM aptitude test was administered in the second week of the first term. Students' aptitude had to be tested right after the new school year started in order to eliminate the influence of learning English in JHS. The surveys on anxiety and motivation were conducted in the seventh week of the same term. These surveys were delayed five weeks because a minimum amount of experience of learning English was needed to respond to the questionnaire, particularly for the non-FLES students, who had no previous exposure to learning English.

\section{Data Analysis}

Each participant responded to eight measures: anxiety, the three components of motivation (interest in FL and FL-speaking people, instrumental motivation, and need for achievement), and the four parts of the aptitude test (auditory memory, phonemic coding, rote memory, and inductive ability). Means and standard deviations of the FLES and non-FLES groups were calculated for each measure. For statistical analysis, a profile analysis (Tabachnick \& Fidell, 2001) was performed on these eight measures of learner characteristics. The primary question was to what extent profiles of the first-year JHS students on learner characteristic measures differ if the students are grouped on the basis of experience with FLES (the parallelism test). Secondary questions were how closely previous learning experience is associated with learner characteristics (the levels test), and whether the pattern of learner characteristics for the combined group is flat (the flatness test).

A total of 12 outlying data points out of 1184 (or about 1\%) were identified and those scores were adjusted to fit within the distributions by moving them to the next highest or lowest score in the group to which they belonged. After deletion of outlying data points, the assumption of homogeneity of variance-covariance matrices $(F=.835, p=.75)$ was found to be met.

The eight measures were converted to $t$-scores in order to make comparisons possible between all of them. This standardization procedure was necessary because the eight measures were not uniform in their possible total scores. For example, each part of the aptitude test was out 
of 100 whereas the motivation measures were each out of 20.

A two-way repeated-measures ANOVA was then used to analyze the dependent variable scores for the effects of the two independent variables, groups and measures, and their interaction. The alpha level was set at .0063 (.05/8) to achieve an experiment wise error rate of .05 (Brown, 1988).

\section{Results}

Table 1 shows the descriptive statistics for the two groups on all eight learner characteristic measures. In each case, the mean (M) and standard deviation (SD) are given; for each subset of the instruments, a reliability coefficient is given. The profile analysis, shown in Figure 1 and Table 2 , deviated significantly from parallelism, $F=3.43, p<.01$. For the levels test, a significant difference was found among groups, $F=5.63, p=.02$. Naturally, no significant differences were found for flatness, $F=0.10, p$ $=1.00$, because all of the means for the measures were set at 50 by the $t$ score transformations.

When the individual deviations from the parallelism of the profiles were examined, the only significant variable was need for achievement (Table 3). In other words, the non-FLES students showed stronger need for achievement $(M=52.18)$ than the FLES students $(M=46.93)$. Notice that the non-FLES students descriptively scored higher than their FLES counterparts in 3 other variables: anxiety, interest in FL and FL-speaking people, and part 4 of the aptitude test. These results may be attributed to the insufficient power of our measures (See Table 3). For future studies a revision of the questionnaire is needed in order to obtain higher reliability and an increase of power. Another solution would be to conduct the survey with a larger sample size.

Tables 4 and 5 show some of the responses to the open-ended questions. The responses of the two groups showed more similarities than differences. Half of the non-FLES students felt insecure about their ability to keep up with the others whereas one-third of the FLES students had the same concern. Around one-fifth of the FLES students and nearly a quarter of the non-FLES students were worried about pronunciation.

\section{Table 1: Descriptive Data of Eight Measures of Learner Characteristics}




\begin{tabular}{llrrr}
\hline Learner Characteristics Measures & Program & $M$ & $S D$ & Reliability \\
\hline Anxiety & FLES & 48.07 & 10.60 & \\
& Non-FLES & 51.35 & 9.38 & \\
& Total & 50.00 & 10.00 & .87 \\
Interest in FLand FL-speaking people & FLES & 48.02 & 10.73 & \\
& Non-FLES & 51.41 & 9.26 & \\
& Total & 50.01 & 10.00 & .62 \\
Instrumental motivation & FLES & 51.16 & 10.29 & \\
& Non-FLES & 49.17 & 9.78 & \\
& Total & 49.99 & 10.01 & .70 \\
Need for achievement & FLES & 46.93 & 10.13 & \\
& Non-FLES & 52.18 & 9.36 & \\
& Total & 50.02 & 9.99 & .62 \\
Aptitude (Part 1) & FLES & 50.80 & 10.80 & \\
(Auditory memory) & Non-FLES & 49.44 & 9.42 & \\
& Total & 50.00 & 10.00 & .85 \\
Aptitude (Part 2) & FLES & 51.18 & 10.80 & \\
(Phonemic coding) & Non-FLES & 49.17 & 9.42 & \\
Aptitude (Part 3) & Total & 50.00 & 10.00 & .78 \\
(Rote memory) & FLES & 48.48 & 10.44 & \\
Aptitude (Part 4) & Non-FLES & 51.07 & 9.60 & \\
(Inductive ability) & Total & 50.00 & 10.00 & .73 \\
& FLES & 47.54 & 10.36 & \\
\hline Notes. & Non-FLES & 51.73 & 9.41 & \\
& Total & 50.00 & 10.00 & .61 \\
\hline & & & \\
& & & & \\
& & &
\end{tabular}

Notes. The $M$ values represent $T$-score means for the eight measures. $n=61$ (FLES), $n=87$ (Non-FLES), $n=148$ (total).

Table 2: Analysis of Variance for Learner Characteristics

\begin{tabular}{lrrrrr}
\hline Source & \multicolumn{1}{c}{$S S$} & Df & \multicolumn{1}{c}{ MS } & \multicolumn{1}{c}{$F$} & \multicolumn{1}{c}{$P$} \\
\hline Between-Subjects Effects & & & & & \\
Groups (levels) & 797.03 & 1 & 797.03 & 5.63 & 0.02 \\
Error & 20652.67 & 146 & 141.46 & & \\
& & & & & \\
Within-Subjects Effects & & & & & \\
Measures (flatness) & 64.65 & 7 & 9.24 & 0.10 & 1.00 \\
Measures by Groups (parallelism) & 2209.43 & 7 & 315.63 & 3.43 & 0.00 \\
Error & 93912.43 & 1022 & 91.89 & & \\
\hline
\end{tabular}


Profiles of eight measures of learner characteristics

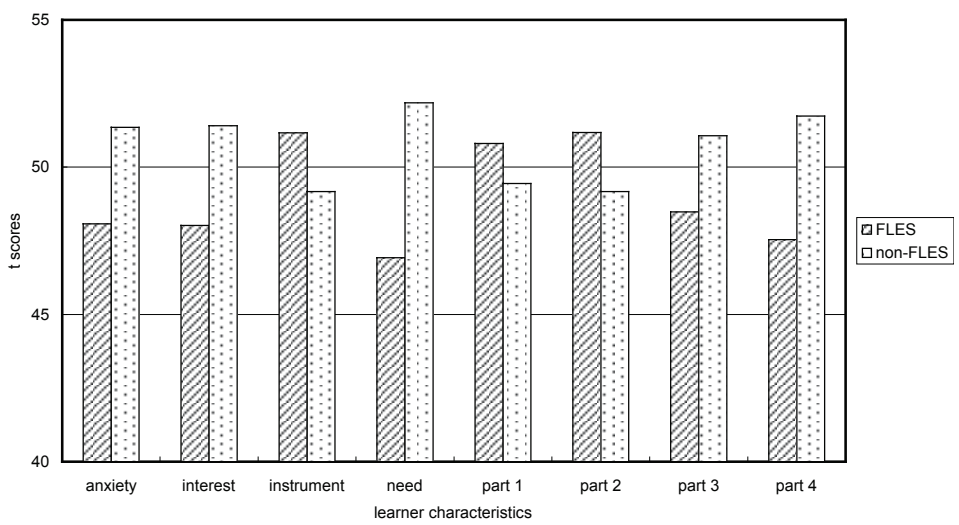

Table 3: Analysis of Variance for Eight Measures of Learner Characteristics

\begin{tabular}{|c|c|c|c|c|c|c|c|}
\hline Source & & $S S$ & $D f$ & $M S$ & $F$ & $p$ & power \\
\hline \multirow[t]{3}{*}{ Anxiety } & Between Groups & 386.78 & 1 & 386.78 & \multirow[t]{3}{*}{3.95} & 0.049 & \multirow[t]{3}{*}{.505} \\
\hline & Within Groups & 14310.47 & 146 & 98.02 & & & \\
\hline & Total & 14697.25 & 147 & & & & \\
\hline \multirow{3}{*}{$\begin{array}{l}\text { Interest in FL and FL- } \\
\text { speaking people }\end{array}$} & Between Groups & 410.79 & 1 & 410.79 & \multirow[t]{3}{*}{4.20} & 0.042 & \multirow[t]{3}{*}{.530} \\
\hline & Within Groups & 14275.82 & 146 & 97.78 & & & \\
\hline & Total & 14686.61 & 147 & & & & \\
\hline \multirow{3}{*}{$\begin{array}{l}\text { Instrumental } \\
\text { motivation }\end{array}$} & Between Groups & 142.32 & 1 & 142.32 & \multirow[t]{3}{*}{1.43} & 0.234 & \multirow[t]{3}{*}{.220} \\
\hline & Within Groups & 14575.06 & 146 & 99.83 & & & \\
\hline & Total & 14717.38 & 147 & & & & \\
\hline \multirow{3}{*}{$\begin{array}{l}\text { Need for } \\
\text { achievement }\end{array}$} & Between Groups & 989.52 & 1 & $989.52 *$ & \multirow[t]{3}{*}{10.56} & 0.001 & \multirow[t]{3}{*}{.898} \\
\hline & Within Groups & 13684.56 & 146 & 93.73 & & & \\
\hline & Total & 14674.09 & 147 & & & & \\
\hline \multirow{3}{*}{$\begin{array}{l}\text { Aptitude (Part 1) } \\
\text { (Auditory memory) }\end{array}$} & Between Groups & 66.35 & 1 & 66.35 & \multirow[t]{3}{*}{0.66} & 0.417 & \multirow[t]{3}{*}{.128} \\
\hline & Within Groups & 14630.80 & 146 & 100.21 & & & \\
\hline & Total & 14697.14 & 147 & & & & \\
\hline \multirow{3}{*}{$\begin{array}{l}\text { Aptitude (Part 2) } \\
\text { (Phonemic coding) }\end{array}$} & Between Groups & 143.72 & 1 & 143.72 & \multirow[t]{3}{*}{1.44} & 0.232 & \multirow[t]{3}{*}{.222} \\
\hline & Within Groups & 14556.42 & 146 & 99.70 & & & \\
\hline & Total & 14700.15 & 147 & & & & \\
\hline \multirow{3}{*}{$\begin{array}{l}\text { Aptitude (Part 3) } \\
\text { (Rote memory) }\end{array}$} & Between Groups & 239.35 & 1 & 239.35 & \multirow[t]{3}{*}{2.42} & 0.122 & \multirow[t]{3}{*}{.339} \\
\hline & Within Groups & 14466.81 & 146 & 99.09 & & & \\
\hline & Total & 14706.16 & 147 & & & & \\
\hline \multirow{3}{*}{$\begin{array}{l}\text { Aptitude (Part 4) } \\
\text { (Inductive ability) }\end{array}$} & Between Groups & 627.63 & 1 & 627.63 & \multirow[t]{3}{*}{6.51} & 0.012 & \multirow[t]{3}{*}{.718} \\
\hline & Within Groups & 14065.15 & 146 & 96.34 & & & \\
\hline & Total & 14692.78 & 147 & & & & \\
\hline
\end{tabular}

${ }^{*} p<.0063$ 


\begin{tabular}{lcc}
\hline Response & $\begin{array}{c}\text { Number of } \\
\text { responses }\end{array}$ & $\begin{array}{c}\text { Percentage } \\
\text { of responses }\end{array}$ \\
\hline I may not be able to keep up with others. & 21 & 34.4 \\
I may not be able to learn vocabulary. & 16 & 26.2 \\
I may not be able to pronounce properly. & 13 & 21.3 \\
I may forget to listen to the radio program. & 7 & 11.5 \\
I'm not sure if I'll be able to communicate with native & 6 & 9.8 \\
speakers. & 6 & 9.8 \\
Imay not be able to meet the course requirements. & &
\end{tabular}

Note. $n=61$

Table 5: Top Five List of Non-FLES Students' Foreign Language Anxiety

\begin{tabular}{lcc}
\hline Response & $\begin{array}{c}\text { Number of } \\
\text { responses }\end{array}$ & $\begin{array}{c}\text { Percentage } \\
\text { of responses }\end{array}$ \\
\hline I may not be able to keep up with others. & 44 & 50.6 \\
I may not be able to pronounce properly. & 21 & 24.1 \\
I may not be able to learn vocabulary. & 16 & 18.4 \\
I may not be able to meet the course requirements. & 6 & 6.9 \\
I'm not sure if I will be able to read English. & 5 & 5.7 \\
\hline
\end{tabular}

Note. $n=87$

\section{Discussion}

These findings suggest that FLES students are not necessarily in a more advantageous position than their non-FLES counterparts in terms of anxiety, motivation, or aptitude. Indeed, the only measure that captured a significant difference between the two groups was the need for achievement, in which non-FLES students surpassed FLES students. These results suggest that FLES, which has been introduced in the hope of enhancing motivation and developing a positive attitude toward learning English, does not lead to substantial benefits, at least for this group.

Anxiety was not a significant variable for the FLES and non-FLES groups. The FLES students were no less anxious than the non-FLES students about learning English despite their previous learning experience. In addition, the responses to the open-ended question revealed similar patterns in the two groups. The number one fear for both groups was whether they would be able to keep up with their classmates. As mentioned before, FLES students take English lessons 
separately from non-FLES students in the first year but they are integrated in the second year. This policy may pose a threat to both groups through different routes. The non-FLES students may assume that they are expected to catch up with FLES students in a year, which seems to be a formidable task for them. FLES students, on the other hand, may regard this policy as an unstated message that the progress they have already made in ES is only a small step towards becoming successful language learners and that the advantages of having learned English in ES will eventually be cancelled out.

Another possible source of anxiety might be the novelty associated with taking a new academic subject in a new setting. Daly (1991) reports that encountering new situations or unfamiliar problems can lead to a tendency to withdraw or remain quiet. In a sense, FLES students may regard English as a new school subject because the teaching methods and the materials as well as the teachers in JHS are unfamiliar to them. They know that games and songs have been replaced by more academically oriented language activities and that homework and quizzes are an important part of language learning in JHS. Their responses to the open-ended question revealed that about $25 \%$ of the FLES students are worried about learning vocabulary and that about $10 \%$ are worried about listening to a daily NHK English program, neither of which were part of the requirements in ES. Judging from the fact that the classroom activities in ES emphasize face-to-face communication that centers on children's familiar situations (Higuchi, Kunikata, \& Hirasawa, 1997; Higuchi, 1997), we can safely say that FLES is Basic Interpersonal Communicative Skill (BICS) oriented. In contrast, language activities in JHS gradually involve Cognitive Academic Language Proficiency (CALP) as learners move on to advanced levels. Learning the different aspect of English may induce apprehension, as anxiety is more directly implicated in the formal activities of language learning than in informal learning (MacIntyre \& Gardner, 1991; Scovel, 1991).

These interpretations, although tentative, may suggest some pedagogical implications. In order to reduce FLES students' apprehension, JHS teachers may assure them that their learning experience in ES is an important asset, and explain clearly that the goals of English learning in ES and in JHS are different. Teachers should incorporate BICS-related activities, which are familiar to them, and phase in CALP-related activities as students move on to higher levels. Meanwhile, teachers should be sensitive to the anxiety of first timers and deal with nervous non-FLES students by paying individual, attention to 
each student. Considering that nearly half of them are afraid they may not be able to keep up with their classmates, teachers should never spare supportive remarks and warm encouragement for their achievements.

No significant differences were found in two subsets of motivation: (1) interest in FL and FL-speaking people, and (2) instrumental motivation. These results contradict the assumption of the Education Ministry that FLES enhances learners' motivation, particularly their interest in FLs and FL-speaking people. The interpretation of these results seems to call for some contextual considerations. A private JHS as a research site implies a relative homogeneity of the student body in terms of academic achievement and family background since it admits students through entrance examinations and interviews. This might explain the relatively high mean scores of both FLES and non-FLES groups in the interest in FL and FL-speaking people $($ FLES, raw mean $=14.00$; non-FLES, raw mean $=$ 14.95, both out of 20.00) and in instrumental motivation (FLES, raw mean $=14.79$; non-FLES, raw mean $=14.01$, both out of 20.00). We do not deny the contribution that FLES may make to the enhancement of motivation, but other factors may also come into play. At this research site, students who are blessed with access to FL-speaking people and opportunities to travel overseas are not uncommon. Some students have parents who have studied or worked in other countries, from whom they receive the message that English is a crucial skill for their future career. These factors may affect their motivation, making the effect of FLES less prominent.

Another potential reason for no statistical differences between the two groups may be attributed to some methodological problems. The statistical power of the survey questionnaire must be increased by upgrading the reliability. As was mentioned in the method section, the questionnaire was short so as to minimize the amount of effort and the time to complete it for fear of burdening students who had been enrolled in JHS for only a few months. Obviously, however, a longer questionnaire would yield more reliable results. Another methodological problem is lack of clarity in the relationship between the questionnaire items and the constructs. We need to clarify the extent to which each statement of the questionnaire adequately reflects the subset of motivation that it is purported to measure. This is difficult because, as Au (1988) contends, one statement can be related to several constructs. However, a refinement of the motivation questionnaire is clearly needed.

The only variable that captured a significant difference was the need for achievement, and what is more, it was the non-FLES students who had a stronger need for achievement. In order to interpret this result, we 
could turn to McClelland, Atkinson, Clark, and Lowell (cited in Skehan, 1989), who, in their theory of need for achievement, maintain that different levels of the need to achieve are the result of previous learning experiences. Their theory posits that, on the basis of former learning experiences, achievers perceive new learning situations as outside their present capabilities but attainable with some effort. It is true that nonFLES students have no previous experience of learning English, but on the basis of their experiences learning other academic subjects, they can be labeled as successful achievers. The private institution where this study was conducted serves kindergarten through university. It accepts students to the ES through a screening process, but automatically promotes them to the affiliated JHS regardless of their academic achievements. The institute also accepts additional students into the JHS, selecting them through entrance examinations that are heavily academically oriented. A typical non-FLES student intensively prepares for entrance examinations at a cram school for at least three years, whereas a typical FLES student has no such learning experience. Thus, non-FLES students perceive themselves as survivors of the entrance examinations, and take pride in the persistence they demonstrated in the process of striving for their goal. Therefore, if we apply this need for achievement theory, we may say that they regard learning any new academic subject as attainable with some effort. Successful achievers may consider a new learning situation to be a welcome challenge because they know that they will gain confidence after achieving their goal. FLES students are just as high achievers as non-FLES students are, but they have not experienced the sense of accomplishment that non-FLES students have as a result of competing in the examinations. Since English is one of the academic subjects in the Japanese school setting, we could speculate that successful achievement in other subjects may help learners build confidence in a general academic context, and hence, may strengthen their need for achievement in a new academic subject, that is, in English. This speculation does not imply support for the "examination hell" students suffer, but it does lend support to Marinova-Todd, Marshall, and Snow's (2000) warning that administrators and parents should not proceed on the assumption that only early FL teaching will be effective.

As was previously mentioned, language learning aptitude was measured to examine whether the FLES/non-FLES distinction in a Japanese private educational institutione also distinguishes the two groups in terms of aptitude as a confounding variable, that is, that non-FLES students may have been differentially selected in the entrance exam based 
on their aptitudes. The statistical analysis showed that the two groups are homogeneous in all four subsets of aptitude. It is noteworthy, however, that we observed large descriptive differences in inductive language learning ability $($ FLES, raw mean $=48.46$; non-FLES, raw mean $=$ 55.89 , both out of $100, p=.012$ ). We should keep in mind the possibility that non-FLES students, with a larger sample size, might show greater inductive language learning ability than their FLES counterparts. For this reason, future studies that pursue the effect of FLES are recommended to examine the aptitude of participants and to confirm that aptitude is not a possible confounding variable.

\section{Conclusion}

The present study failed to find positive effects for FLES on any of the eight measures of learner characteristics. Although it does not necessarily mean that there could not be an effect, it does suggests that FL anxiety and motivation are complex constructs that might be affected by factors other than the starting age of FL learning; for example, academic and family background. It offers some empirical evidence for Wada's (1996) suspicion that FLES is not a panacea for solving the problems that confront English language teaching in secondary schools. He expresses strong doubts about the widespread belief in today's Japan that children who learn English in ES will continue to be interested in the language in later stages of language learning. This study adds some empirical evidence to support his concern. The guidelines published by the Ministry of Education (2001) are based on the assumption that FLES is effective in motivating learners, but this seems to require critical reappraisal. Hunches, intuitive judgments, and common notions presented as facts should not be accepted "unless they can be given rational sanction" (Widdowson, 1990, p. 2). All this urges caution against the overestimation of FLES as a motivation booster.

This researcher is well aware of some of the methodological objections to the study. One possible objection is related to the questionnaire design. A clearer relationship between the questionnaire items and the motivational constructs to be measured should be established. An increased number of questionnaire items will also augment reliability. However, even if we devised a more reliable test instrument and decided to administer it, we would then need to consider problems related to administering a time-consuming questionnaire to JHS students. Another possible objection is that the pattern of results obtained in this study may be peculiar to a Japanese private school setting, and therefore, 
lack generalizability. A replication of this study is needed in different educational contexts, particularly in public schools, because they are free from the selection bias that is inevitable in private schools. Further research with more refined instruments will broaden the perspective of FLES and provide insights into policy making for English teaching in Japan.

\section{Acknowledgements}

I would like to thank two anonymous reviewers for reading the manuscript and making a number of helpful suggestions.

Tomoko Takada is a teacher at Gakushuin Girls' Junior and Senior High School. She also lectures at Gakushuin University and Gakushuin Women's College. Her research interests include teaching writing and learner characteristics.

\section{References}

Asaba, R., Ishida, M., \& Kobayashi, H. (1998). Eigo ka kyoiku ho no jittai [The training of English teachers in Japan]. The English Teachers' Magazine, 46 (11), 11-13.

Au, S. Y. (1988). A critical appraisal of Gardner's social-psychological theory of second language (L2) learning. Language Learning, 38 (1), 75-100.

Brown, J. D. (1988). Understanding research in second language learning. Cambridge: Cambridge University Press.

Brown, J. D. (2001). Using surveys in language programs. Cambridge: Cambridge University Press.

Burstall, C. (1975). Primary French in the balance. Educational Research, 17 (3), 193-198.

Carroll, J. (1981). Twenty-five years of research on foreign language aptitude. In $\mathrm{K}$. Diller (Ed.), Individual differences and universals in language learning aptitude (pp. 83-118). Rowley, MA: Newbury House.

Clément, R. \& Kruidentier, B. G. (1983). Orientations in second language acquisition: I. The effects of ethnicity, milieu, and target language on their emergence. Language Learning 33 (3), 273-291.

Crookes, G. \& Schmidt, R. W. (1991). Motivation: Reopening the research agenda. Language Learning, 41 (1), 459-512.

Daly, J. (1991). Understanding communication apprehension: An introduction for language educators. In E. Horwitz \& D. Young (Eds.), Language learning anxiety: From theory and research to classroom implications (pp. 3-13). Englewood Cliffs, NJ: Prentice Hall.

Dörnyei, Z. (1990). Conceptualizing motivation in foreign-language learning. 
Language Learning, 40 (1), 45-78.

Dulay, H., Burt, M., \& Krashen, S. (1982). Language two. Oxford: Oxford University Press.

Ekstrand, L. H. (1982). English without a book revisited: The effect of age on second language acquisition in a formal setting. In S. D. Krashen, M. A. Long, \& R. C. Scarcella (Eds.), Child-adult differences in second language acquisition (pp. 136-158). Rowley, MA: Newbury House.

Ellis, R. (1985). Understanding second language acquisition. Oxford: Oxford University Press.

Ellis, R. (1994). The study of second language acquisition. Oxford: Oxford University Press.

Fledge, J. E. (1987). A critical period for learning to pronounce foreign languages? Applied Linguistics, 8 (2), 162-177.

Gardner, R. C. (1985). Social psychology and second language learning: The role of attitudes and motivation. London: Edward Arnold.

Gardner, R. C. \& Lambert, W. E. (1972). Attitudes and motivation in secondlanguage learning. Rowley, MA: Newbury House.

Higuchi, T. (1987). Jido eigo gakushu sha no tsuiseki chosa ga shisa suru mono [Implications of the follow-up surveys of learners who started learning English at early ages]. In JASTEC (Eds.), Jido eigo kyoiku no joshiki [What you should know about teaching English to children] (pp. 37-47). Tokyo: Kyobundo.

Higuchi, T. (1990). Kodomo no toki kara eigo wo manande iru hito tachi ni tsuite kagaku teki chosa ha okonawarete iruka [Have any scientific studies been conducted on learners who learned English in childhood?]. In In Goto, T., Igarashi, J., Ito, K., Goto, N., Nogami, M., Higuchi, T., \& Yukihiro, T. (Eds.). Jido eigo shido ho handbook [A handbook for teaching English to children] (pp. 39-42). Tokyo: Apricot.

Higuchi, T. (1997). Shogakko ni okeru gaikokugo kyoiku no hoko [Foreign language teaching in elementary school]. In Higuchi T., Kunikata, T., \& Hirasawa, K. (Eds.), Shogakko kara no gaikokugo kyoiku [Foreign language teaching in elementary school] (pp. 152-158). Tokyo: Kenkyusha.

Higuchi, T. (1999). Soki eigo kyoiku no susume [Advantages of teaching English to children]. The English Teachers' Magazine, 48 (8), 8-10.

Higuchi, T., Kitamura, T., Moriya, M., Miura, I., \& Nakayama, K. (1986). Soki eigo gakushu keikensha no tsuiseki chosa dai ippo [A follow-up study of learners who learned English at early ages, No. 1]. JASTEC, 5, 49-67.

Higuchi, T. Kitamura, T., Moriya, M., Miura, I., Nakayama, K, \& Kunikata, T. (1987). Soki eigo gakushu keikensha no tsuiseki chosa dai niho [A follow-up study of learners who learned English at early ages, No. 2]. JASTEC, 6, 3-21.

Higuchi, T., Kunikata, T., \& Hirasawa, K. (1997). Shogakko ni okeru gaikokugo kyoiku no curriculum shian [A curriculum plan of foreign language teaching in elementary school]. In Higuchi T., Kunikata, T., \& Hirasawa, K. (Eds.), Shogakko kara no gaikokugo kyoiku [Teaching foreign languages in elementary school] (pp.158-171). Tokyo: Kenkyusha.

Higuchi, T., Kunikata, T., Miura, I., Kitamura, T., Nakamoto, M., \& Moriya, M. 
(1994). Soki eigo gakushu ga gakushusha no eigo oyobi gaikokugo gakushu ni okeru taido to doki ni oyobosu eikyo [The effect of English learning at an early stage on motivation and attitudes toward English and foreign language learning]. JASTEC, 13, 35-48.

Horwitz, E. K., Horwitz, M. B., \& Cope, J. (1986). Foreign language classroom anxiety. Modern Language Journal, 70 (2), 125-132.

Ito, K. (1987). Saikin no gengo shutoku riron to jido eigo kyoiku [Current theories of second language acquisition and teaching English to children]. In JASTEC (Eds.), Jido eigo kyoiku no joshiki [What you should know about teaching English to children] (pp. 19-29). Tokyo: Kyobundo.

Ito, K. (1990). Nan sai kurai kara eigo wo manabi hajimeru noga yoika [Optimal ages to start English language learning]. In Goto, T., Igarashi, J., Ito, K., Goto, N., Nogami, M., Higuchi, T., \& Yukihiro, T. (Eds.). Jido eigo shido ho handbook [A handbook for teaching English to children] (pp. 19-29). Tokyo: Apricot.

Ito, K. (1997). Gakko gaikokugo kyoiku no kiso to shite no shogakko gaikokugo kyoiku [Teaching English in elementary school as a foundation of teaching foreign languages in a school system]. In Higuchi T., Kunikata, T., \& Hirasawa, K. (Eds.), Shogakko kara no gaikokugo kyoiku [Teaching foreign languages in elementary school] (pp. 239-246). Tokyo: Kenkyusha.

Kobayashi, Y. (1996). Shogakko deno eigo kyoiku no mondai ten [Problems of English language teaching in elementary school]. Hoso Kyoiku, 51 (4), 1113.

Konishi, M. (1994). Dai ni gengo shutoku ni okeru gakushusha yoin [Learner factors in second language acquisition]. In I. Koike, (Ed.), Dai ni gengo shutoku kenkyu ni motozuku saishin no eigo kyoiku [English teaching based on the latest second language acquisition research] (pp. 127-146). Tokyo: Taishukan.

Krashen, S. D., Long, M. A., \& Scarcella, R. C. (1979). Age, rate and eventual attainment in second language acquisition. TESOL Quarterly, 13 (4), 573582.

Kuniyoshi, T. (1996, February 7). Chikyu jidai wo ikiru tame ni [To survive the global age]. Kinyobi, 21-22.

Kuno, Y. (1987). Eigo no on ni shitashimu tame ni [Familiarizing children to spoken English]. In JASTEC (Eds.), Jido eigo kyoiku no joshiki [What you should know about teaching English to children] (pp. 119-129). Tokyo: Kyobundo.

Kuno, Y. (1990). Jido eigo kyoiku dewa kodomo tachi no kanousei wo dokomade hikidasu koto ga dekiruka [To what extent can English language teaching help develop children's possibilities?]. In Goto, T., Igarashi, J., Ito, K., Goto, N., Nogami, M., Higuchi, T., \& Yukihiro, T. (Eds.). Jido eigo shido ho handbook [A handbook for teaching English to children] (pp. 82-84). Tokyo: Apricot.

MacIntyre, P. D. \& Gardner, R. C. (1991). Methods and results in the study of anxiety and language learning: A review of the literature. Language Learning, 41 (1), 85-117. 
MacIntyre, P. D. \& Gardner, R. C. (1994). The subtle effects of language anxiety on cognitive processing in the second language. Language Learning, 44 (2), 283-305.

Marinova-Todd, S. H., Marshall, D. B., \& Snow, C. E. (2000). Three misconceptions about age and L2 learning. TESOL Quarterly, 34 (1), 9-34.

McLaughlin, B. (1992). Myths and misconceptions about second language learning: What every teacher needs to unlearn (Report No. EDO-FL-91-10). College Park, MD: ERIC Clearinghouse on assessment and evaluation.

Megumi, T., Yokokawa, H., \& Miura, I. (1996). Soki eigo gakushu keikensha no chu ko ni okeru seiseki [High school grades in early learners of English]. JASTEC, 15, 27-35.

The Ministry of Education, Culture, Sports, Science, and Technology. (2001). Shogakko eigo katsudo jissen no tebiki [Practical handbook for elementary school English activities]. Tokyo: Author.

Nakayama, K. (1990). Jido eigo kyoiku no riso wo mezashi nagara chugaku eigo ni do tsunageru ka [The coordination between elementary and secondary English language programs]. In Goto, T., Igarashi, J., Ito, K., Goto, N., Nogami, M., Higuchi, T., \& Yukihiro, T. (Eds.). Jido eigo shido ho handbook [A handbook for teaching English to children] (pp. 58-61). Tokyo: Apricot.

Nikolov, M. (2000). The critical period hypothesis reconsidered: Successful adult learners of Hungarian and English. IRAL, 38, 109-124.

Noels, K. A. (2001). New orientations in language learning motivation: Towards a model of intrinsic, extrinsic, and integrative orientations and motivation. In Z. Dörnyei \& R. Schmidt (Eds.), Motivation and second language acquisition (pp. 43-68). Honolulu: University of Hawai'i at Mănoa.

Oller, J. W. \& Nagato, N. (1974). The long-term effect of FLES: An experiment. The Modern Language Journal, 58 (1)-(2). 15-19.

Patkowski, M. S. (1980). The sensitive period for the acquisition of syntax in a second language. Language Learning, 30 (2), 449-472.

Price, M. L. (1991). The subjective experience of foreign language anxiety: Interviews with highly anxious students. In E. Horwitz \& D. Young (Eds.), Language learning anxiety: From theory and research to classroom implications (pp. 101-108). Englewood Cliffs, NJ: Prentice Hall.

Scovel, T. (1991). The effect of affect on foreign language learning: A review of the anxiety research. In E. Horwitz \& D. Young (Eds.), Language learning anxiety: From theory and research to classroom implications (pp. 15-23). Englewood Cliffs, NJ: Prentice Hall.

Shirahata, T. (1994). Nenrei to dai ni gengo shutoku [Age and second language acquisition]. In Koike, I., (Ed.), Dai ni gengo shutoku kenkyu ni motozuku saishin no eigo kyoiku [English language teaching based on second language acquisition theory] (pp. 147-166). Tokyo: Taishukan.

Shirahata, T. (1998). Gaikokugo gakushu no rinkaiki wo meguru giron [Discussion on the critical period hypothesis]. The English Teachers' Magazine, 47 (3), 8-10. 
Shirahata, T. (1999). Shogakko eno eigo donyu ga kakaeru kadai [Problems of introducing English language teaching to elementary school]. The English Teachers' Magazine, 48 (8), 14-16.

Shirahata, T. (2002). An investigation into English abilities of the students who were exposed to English at a model school. Bulletin of the faculty of education, Shizuoka University, 33, 195-215.

Sick, J. \& Irie, K. (2000). The Lunic language marathon: A new language aptitude instrument for Japanese foreign language learners. Individual differences in foreign language learning: Effects of aptitude, intelligence, and motivation (pp. 173-185). Tokyo: Japan Association for Language Teaching Special Interest Group for Material Writers.

Skehan, P. (1989). Individual differences in second-language learning. London: Edward Arnold.

Snow, C. E. \& Hoefnagel-Höhle, M. (1977). Age difference in the pronunciation of foreign sounds. Language and Speech, 20 (4), 357-356.

Tabachnick, B. G., \& Fidell, L. S. (2001). Using multivariate statistics. Needham Heights, MA: Allyn \& Bacon.

Tokyo kyoiku daigaku fuzoku chuugakko eigo ka [The English Department, The Junior High School Attached to the Tokyo University of Education]. (1970). Shogakko ni okeru eigo gakushu no koka ni kansuru tsuiseki chosa [A study on the effect of English language learning in elementary school]. The English Teachers' Magazine, 18 (12), 16-21.

Wada, M. (1996). Koritsu shogakko no eigo kyoiku: Sono ronten wo seiri suru [English language teaching in public schools: Some points of argument]. The English Teachers' Magazine, 45 (2), 17-19.

Widdowson, H. G. (1990). Aspects of language teaching. Oxford: Oxford University Press.

\section{Appendix}

The 32 Items in the anxiety/motivation questionnaire (Japanese version)

1. 英語の授業で間違いをしても気にしない。

2. 授業中、自分があたると思うと不安になる。

3. 先生が英語で話していることがわからないと、不安になる。

4.もっと英語の時間があってもよい。

5. 自分より他の人の方が英語できると思う。

6. テストでは緊張しない。

7. 悪い成績をとらないかと心配になる。

8. 英語の授業はとても緊張する。

9. 授業中、自分から発言するのは恥ずかしい。 
10。 ホリエ先生と英語で話す時、緊張しない。

11 . 英語で答える時、自信をもって発言できる。

12 . 先生が、自分の間違いを全部直すのではないかと心配になる。

13 . 自分があたる番になると、心臓がどきどきする。

14 . クラスの人の前で英語で発言するのははずかしい。

15 . 英語の授業は早く進むので、取り残されるのではないかと心配 になる。

16 . 英語の時間は、他の科目の授業より緊張する。

17 . 英語の授業が始まる前は、楽な気持ちである。

18 ．先生のおつしゃる英語が全部わからないと、不安になる。

19 . 英語を話せるようになるために覚えることが多くて、圧倒され る。

20 . 英語を母国語とする人と一緒にいても緊張しないと思う。

2 1. チャンスがあれば留学したいと思う。

22 . 英検（実用英語検定試験）をとりたいと思う。

23 .これからの社会では英語を使えることが大事だと思う。

24 . 将来、英語を使う仕事をしたいと思う。

25 . 英語の授業は楽しい。

26 ．英語のほかにも外国語を勉強したいと思う。

27 . 英語を通してほかの国の文化を学びたいと思う。

2 8. 英語を使ってほかの国の人と友達になりたいと思う。

29 . 基礎英語を聞いている。

30 . 英語の教科書の復習をする。

31 . 英語でよい成績をとりたいと思う。

32 ．英語を勉強するのは、自分にとって大事なことである。

The Items in the anxiety/motivation questionnaire (English Version)

Endorsement of items \#1 through \#20 was interpreted as indicating language learning anxiety.

1. I don't worry about making mistakes in English class.

2. I get nervous when I know that I'm going to be called on in English class.

3. I get nervous when I don't understand what the teacher is saying in English.

4. It wouldn't bother me at all to take more English language classes.

5. I think that the other students are better at English than I am.

6. I am usually at ease during tests in English class.

7. I worry about getting poor grades in English.

8. In English class, I get very nervous.

9. It embarrasses me to volunteer answers in English class. 
10. I am not nervous speaking English with Mrs. Horie, my nativespeaking teacher.

11. I feel confident when I speak in English class.

12. I am afraid that my English teacher is ready to correct every mistake I make.

13. I can feel my heart pounding when I'm going to be called on in English class.

14. I feel very self-conscious about speaking English in front of other students.

15. English class moves so quickly that I worry about getting left behind.

16. I feel more tense and nervous in English class than in other classes.

17. When I'm on my way to English class, I feel relaxed.

18. I get nervous when I don't understand every word the English teacher says.

19. I feel overwhelmed by the number of rules we have to learn to speak English.

20. I would probably feel comfortable around native speakers of English.

Endorsement of the items \#21 through \#24 was interpreted as indicating instrumental motivation.

21. I would like to study abroad in the future.

22. I would like to take a STEP (Society of Testing English Proficiency) exam.

23. I think English proficiency is an essential skill for my future.

24. I would like to choose a career that requires English proficiency.

Endorsement of the items \#25 through \#28 was interpreted as indicating interest in FL and FL-speaking people

25. I enjoy taking English classes.

26. I am interested in learning foreign languages other than English.

27. I am interested in learning other cultures by learning English.

28. I am interested in making friends with people from other countries by communicating in English.

Endorsement of the items \#29 through \#32 was interpreted as indicating need for achievement.

29. I never skip an English radio program lesson.

30. I study English at home every day.

31. I want to get good grades in English.

32. Learning English is an important thing for me. 